\title{
ANALYSING THE SOCIO DEMOGRAPHIC FACTORS AFFECTING FINANCIAL LITERACY OF THE INDIAN YOUTH: A SPECIAL CASE OF COLLEGE STUDENTS IN HIMALAYAN REGION
}

\author{
Dr. Divya Ghai \\ Dev Bhoomi Group of Institutions, Dehradun, Uttarakhand, India \\ Dr. Praveen Singh \\ Graphic Era Deemed to be University, Dehradun, Uttarakhand, India
}

\begin{abstract}
In India, financial literacy has been at alarmingly low levels over the years. Improving the levels of financial literacy in a society requires a deep understanding of the socio-economic and demographic variables that affect it. In order to formulate a national financial education policy, the government needs empirical evidence that indicates the level of demand among people and in specific subgroups. This research paper collected primary data of financial knowledge and behaviour of young students studying in colleges of North India. A binary logistic regression model was developed for the analysis of the socio-demographic variables that affected financial literacy during the recent pandemic. Education of youth, mother's education, family's income and the financial behaviour of parents seemed to have the most impact. Similar studies can be conducted for different geographical areas and different time periods.
\end{abstract}

Key words: financial literacy; empirical evidence of financial literacy; financial education; financial knowledge; overall financial knowledge; general financial knowledge; personal financial planning; financial skills; financial attitudes; financial behaviour; financial decisions; perception; youth; college students; demographic variables; socio demographic variables; determinants of financial literacy; risk management; north India; India.

Cite this Article: Divya Ghai and Praveen Singh, Analysing the Socio Demographic Factors Affecting Financial Literacy of the Indian Youth: A Special Case of College Students in Himalayan Region, International Journal of Management, 11(12), 2020, pp. 2476-2499.

http://iaeme.com/Home/issue/IJM?Volume=11\&Issue $=12$ 


\section{INTRODUCTION}

Financial knowledge has been identified as an important life skill, especially in the increasingly complex financial products and services in the world. For a long time, India's low level of financial knowledge has been a problem. Various polls including Standard \& Poor's Global Financial Literacy Survey indicate that more than $76 \%$ of adults in India do not understand the basics of financial planning. The central government's flagship financial inclusion drive Pradhan Mantri Jan Dhan Yojana (PMJDY) launched about six years ago has significantly improved the level of financial inclusiveness, so much so that more than 40 crore bank accounts have been opened till July 2020, and there are about 40.05 crore beneficiaries of this scheme and deposits in Jan Dhan bank accounts are in excess of 1.30 lakh crore rupees (as per a report published in The Hindu newspaper dated $3^{\text {rd }}$ August 2020) but in an absolute sense, this means that India still has a large population without bank accounts. The strange reality here is that increasing financial inclusion levels don't seem to have a significant positive impact on the way individuals plan their financial future, take care of their savings, investments, buying habits and manage their day to day expenses.

The Organisation for Economic Co-operation and Development (OECD) has provided a definition of financial literacy which has been extensively used across several countries. Use of such a widely accepted definition ensures that we are able to benchmark the results against the results of the world around us. The OECD has proposed a definition that is sufficient to cover this idea. In this definition, financial education is considered to be a combination of knowledge, awareness, abilities, attitudes and behaviors necessary to make reasonable financial decisions and ultimately achieve personal financial health (OECD, 2013).

Improving the levels of financial literacy requires a deep understanding of the socioeconomic and demographic variables that affect it. This will also give us indications about the policy changes that are required to be made in order to ensure a marked improvement in the levels of financial literacy over a span of next few years.

Low levels of financial literacy are validated in the S\&P Global Fin Lit Survey (Nov.2015), which is the world's largest, most comprehensive global measurement of financial literacy. Worldwide only $35 \%$ of men and $30 \%$ of women are financially literate. India very clearly lies in the bracket of $0-24 \%$ adults who are financially literate. (Fig.1)

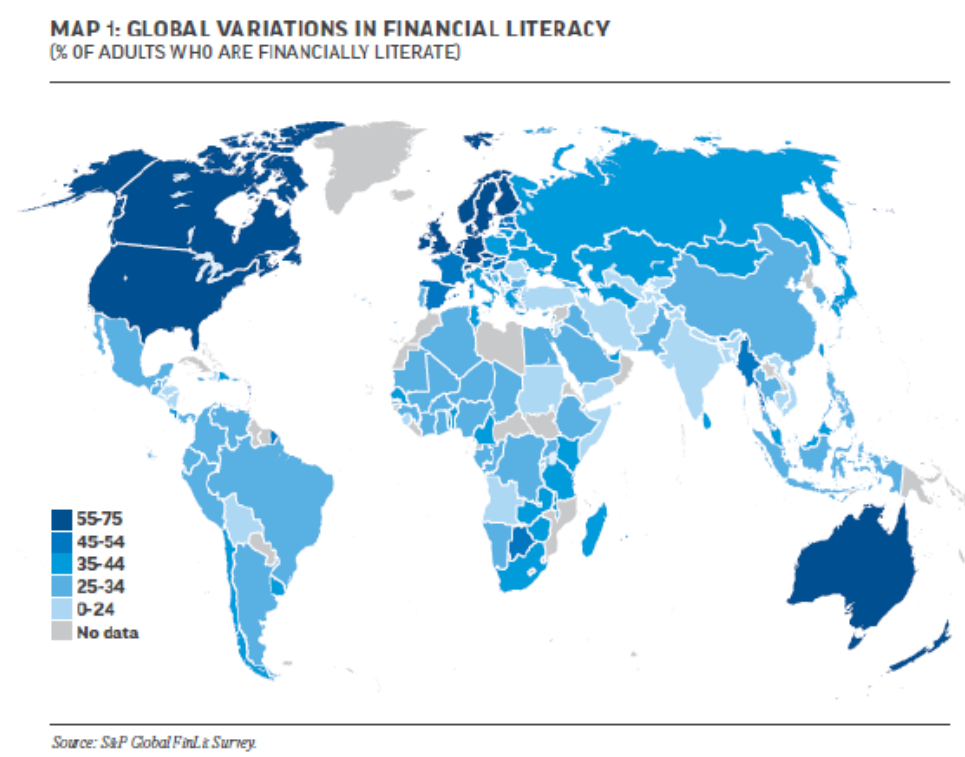

Figure 1 Financial Literacy across the Globe

Source: S\&P Global Financial Literacy Survey Report (Nov.2015) 
In India, all the present efforts of increasing financial literacy are more or less limited to conducting informational seminars by various asset management companies and ultimately promoting their products. There is no talk about teaching the basics of financial literacy or behavioral finance to the adults and particularly young adults. These young adults are the people who have never been exposed to any kind of training about finance in school or college. As in most countries, in India, we do our best to teach children to read and write, but we do not pay equal attention to their financial knowledge. As a result, few young people know how to manage their personal financial life.

In Fig. 2 it is evident that the levels of financial literacy have not been satisfactory in most of the countries. Among the major emerging economies, the so-called BRICS (Brazil, Russian Federation, India, China and South Africa) have an average of $28 \%$ of adults with financial literacy. There is also a gap between these countries. According to the S\&P Global Financial Literacy Survey, the rate ranges from $24 \%$ in India to $42 \%$ in South Africa.

Over $50 \%$ of India's population is under 25 and over $65 \%$ are under 35 . By 2020 , the average age in India is estimated to be 29, compared with 37 in China and 48 in Japan. This demonstrates the utmost importance of penetration of financial literacy among youth. If we are able to devise ways to incorporate a good understanding of financial literacy among them, that will yield good results for a long time to come.

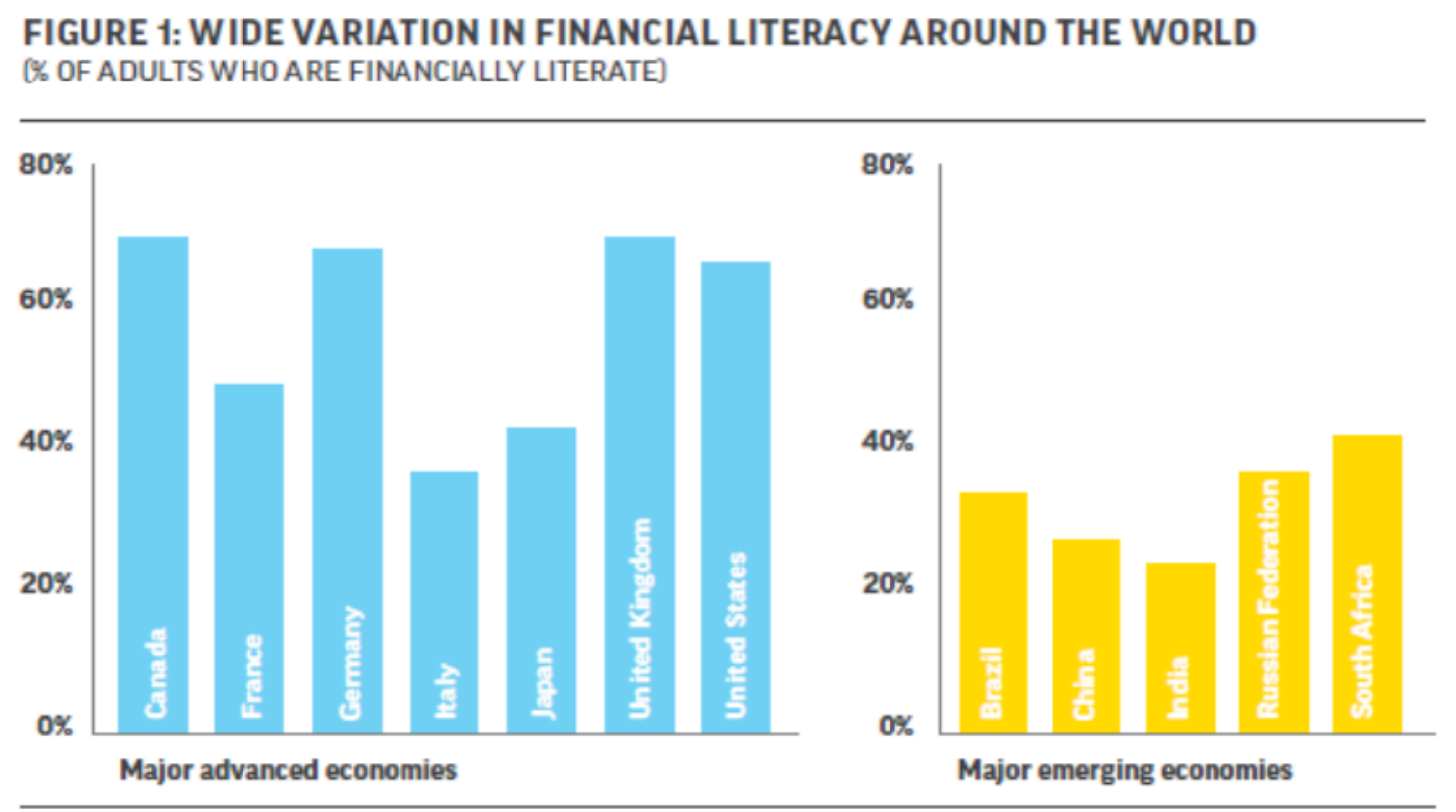

Source: SaP Gobal FinLir Survey

Figure 2 Comparative View of the Financial Literacy Levels Globally

Source: S\&P Global Financial Literacy Survey Report (Nov. 2015)

Visa Research (2012) ranked India 23rd out of 28 countries surveyed. The questionnaire prepared by the Organization for Economic Cooperation and Development (OECD) which is commonly adopted by researchers of financial literacy has also been used in this study. The average score of India is 13.8, in the 13 countries/regions surveyed by the OECD research report (which is within the average score range of 12.4 to 15.1 ). It is shocking that only about $39 \%$ of the employees surveyed have a financial education score higher than the OECD average. The similar figure for retirees is about $56 \%$. This seems to indicate that for most young employees and a large number of retired Indians, the level of financial education is not very high. According to this study, India is far ahead of several countries including South Africa, Armenia, 
Poland, Estonia and Albania. But in India, financial behavior scores are relatively high, while most of the studies have confirmed that India's overall financial education is poor.

Another study conducted on the basis of OECD questionnaire was the one done by IIM Ahmedabad students who included students, young employees and retirees in their study. The surprising conclusion is that compared with global standards, India's financial knowledge is very scarce. This must be founded in poor mathematical skills provided by poor primary education system as demonstrated in other studies. But the overall financial knowledge scores are still comparable to the recognized poor global standards as good financial behaviour is influenced by families a lot in India (Agarwalla et al., 2013). It is interesting that there are usually some context variables that affect financial education across several countries. Discovering the variables that influence financial education would help us in formulating specific intervention strategies for each country. Developing a multidimensional model can help us understand the reasons behind low levels of financial literacy across countries. Government can use that model in policymaking and the players in this sector can design products and services in an efficient manner.

\section{THEORETICAL FRAMEWORK}

\subsection{Meaning of Financial Literacy}

The OECD definition regards financial education as a process for people to improve their understanding of financial products and concepts; and develop skills and confidence through objective information, guidance and/or advice, to better understand financial risks and opportunities, and make smart decisions, know where to seek help and take other effective measures to improve your financial situation. Existence and Protection (OECD, 2005).

As demonstrated by the comprehensive definition given by OECD, financial literacy encompasses other related concepts as well. Increase in financial literacy levels improves a person's overall confidence and sentiment about the future and may also help them in making better decisions. However, financial literacy alone does not guarantee financial security. To make long-term major changes in people's lives, it is not the only factor necessary to have a basic understanding of financial education and related concepts. Financial literacy is the combination of awareness, knowledge, skills, attitudes and behaviors required to make reasonable financial decisions and ultimately achieve personal financial status. So it's not just about balancing laptops, comparing prices while shopping or getting related jobs. It also includes skills such as long-term vision, planning for the future, as well as the discipline to use these skills on a daily basis, depending on conditions related to financial attitudes and behavior.

Now, governments all over the world recognize that financial knowledge is a core skill, which is why they are interested in finding effective ways to improve their level in the population, and many countries are also working hard to develop a national education strategy. In the process of formulating a national financial education strategy, the government will certainly benefit from empirical evidence that indicates the level of demand among people and in specific subgroups. In order to effectively provide financial education and evaluate its impact at the national level, measuring the current level of financial education is an important prerequisite.

The results of extensive financial education surveys for different sub-groups in specific countries/regions can be used as reference and then used to establish benchmarks for corresponding financial education programs. Follow-up investigations can be conducted to determine the changes that occurred during the transition period. Through this measurement method, policymakers can identify potential needs and gaps related to specific aspects of financial education and provide information about which groups of people need this support the most. 
Analysing the Socio Demographic Factors Affecting Financial Literacy of the Indian Youth: A

Special Case of College Students in Himalayan Region

Attitudes and preferences are considered important components of financial education. For example, if people have a rather negative attitude towards preserving their future, they will be less inclined to adopt this behavior. Similarly, if they tend to prioritize short-term wishes, they are unlikely to provide for emergency savings or develop long-term financial plans.

Over the years liberalization and globalization has resulted in the flooding of several complex products and services in the financial markets and the rapid economic growth of India owing to privatization has given way to banks, non-banking financial institutions and other players to introduce many financial products in investments, loans and similar segments. But lower level of financial knowledge prevents people from understanding these alternatives clearly and making correct decisions in their finances. In order to achieve long-term wealth goals, individuals must capitalize their savings into suitable investment options.

The financial system of a country has a major role to play in the economic development. Since independence, the goal of India has been to remove poverty and make India a dynamic and self-sufficient global economy, and the need for financial education has been rooted in the lives of all citizens. Traditionally, India has been an enthusiastic saver. Indians suffer from low insurance levels, debt traps, inadequate retirement funds, and low levels of financial education leading to low investment returns.

Based on the OECD's recommendations, India established a high-level institutional structure under the auspices of the Financial Stability and Development Council (FSDC) in 2011. The "Financial Inclusion and Financial Literacy Group" led by the governor RBI and the National Financial Education Center was established to improve the financial capabilities of 500 million adults.

\section{LITERATURE REVIEW}

Financial education and its various components and concepts have been defined and explained differently by different financial experts over the years. Financial education is often confused with financial literacy or financial knowledge, though the two concepts are quite different and obviously this synonymous usage will cause practical problems. After doing extensive literature review of the studies on financial literacy, Xu and Zia (2012) and Huston (2010) proposed that presence of financial literacy essentially means presence of financial knowledge as the two concepts cannot independently exist. Financial knowledge covers many concepts, including financial awareness and knowledge, financial skills and financial capabilities but it is certainly not easy to actually analyze in a limited time as to how this financial knowledge will be processed by them and used in making decisions as elucidated by Lusardi and Mitchell (2011).

As the field of financial education has widened and more research has been done by various experts in this field, various definitions have come forth, but these definitions differ a lot in their understanding of the concept of financial education. Robb, Babiarz, and Woodyard (2012) opine that financial literacy means the ability to understand financial information and use that information to make effective decisions, on the other hand, financial education only refers to remembering numbers and facts. So, according to their findings, the main focus of financial education is only knowledge. Some experts like Mccormeck (2009) and Huston (2010) concluded that financial education is a much wider concept than financial education. They have identified other important concepts like financial behavior and attitude to be a part of financial knowledge.

The OECD has given a much more comprehensive definition that covers all the important aspects of financial literacy. It considers financial education to be a combination of four factors namely, consciousness, knowledge, skills, attitudes and behaviors. Therefore, the OECD definition suggests three aspects to study financial literacy namely, financial knowledge, 
financial behavior and financial attitude. In this study, we also acknowledge this definition as the most appropriate definition and it is the most widely accepted one too.

Financial knowledge refers to the basic knowledge of general financial concepts that have been developed over the years by studying different topics and particularly relate to managing income, expenditure, and savings (Delavande, Rohwedder, and Willis, 2008). Financial behaviors such as spending, planning and creating financial security is another important element of financial education and generally turns out to be the most important one (OECD, 2013, Atkinson and Messy, 2012). The financial attitude is the factor which is totally subjective to the decision maker. The conditioning and upbringing of the individual define the various economic and non-economic beliefs held by individuals and this leads to certain financial behaviors in every-day life. Ajzen, 1991 has found the combination of financial attitudes to be a key factor in the individual's financial decision-making process.

Different researchers hold different views on the true composition of financial education. Some terms are used interchangeably, such as financial knowledge, financial education and financial literacy. Some researchers measure it through other broader aspects, such as financial behavior, financial attitude, financial experience, etc. A lot of research has been conducted in different regions of the world and they have come out with different definitions, but for the purpose of standardizing the concept for better comprehension and understanding, OECD definition has been accepted to be the most appropriate till now.

\subsection{Correlation Between Different Variables and Financial Literacy}

\section{Global Studies}

Various studies across the globe have indicated towards a major influence of demographic and socioeconomic factors on the levels of financial literacy in different countries. Many studies have demonstrated that age, gender, marital status, level of education of the respondent and his family, their occupations, number of dependents, family income, standard of living, their social exposure and many such factors play an important role in determining the level of financial literacy of that individual.

It has been observed that females are generally answering the questions incorrectly and they might just avoid the questions altogether by simply stating that they don't know the answer. Various studies like Lusardi and Mitchell (2011), Lusardi \& Wallace (2013) and Chen and Volpe (1998) establish that gender is a significant factor here. Females are found to be very skeptical about their own level of financial knowledge. They assess their own financial literacy level negatively in comparison to others often. Surprisingly, this remains similar across developed and developing countries. Some studies concluded that women find performing financial calculations difficult and have lower level of financial knowledge and as a result they lack the ability to make right financial decisions.

Calamato (2010) found that way men and women perceive money very differently. Men relate to money as it gives them a sense of power and they believe that having money will fulfill their social needs too, on the other hand, women were found to have a rather passive approach to money. Edwards et.al. (2007) concluded that parents are more likely to talk about money with their sons only. Similar conclusions were drawn by different studies conducted in different countries like Agnew and Szykman (2005), Lusardi and Mitchell (2011), Van Rooij, et al. (2011), Lusardi and Tufano (2009).

Another influential demographic factor is age. Financial literacy levels seem to be different in different age groups. Most of the research points out that very young adults or very old people do not possess satisfactory levels of financial knowledge and skills. Several studies support the finding that the financial literacy is highest in the middle of the adult's life cycle, and is usually lowest among young and old (Research, 2003; Agarwal, Driscoll, Gabaix \& Laibson, 2009; 
Analysing the Socio Demographic Factors Affecting Financial Literacy of the Indian Youth: A

Special Case of College Students in Himalayan Region

Lusardi and Mitchell, 2011). Shim, Barber, Card, Xiao, and Serido (2010) and Scheresberg (2013) found that young people and college students tend to make risky financial choices more often. Only a few students try to learn how to better manage their financial situation, others engage in risky behavior.

Research (2003) and Brown and Graf (2013) have proved that married people have a significantly higher level of financial knowledge as compared to young people. People with a low level of financial literacy are more likely to make wrong financial decisions, which will in turn endanger their relationship due to possible financial crisis (Calamato, 2010). Married people have a higher level of financial literacy as they are worried about consumer debts which might cause tension in their marital life.

People with a greater number of dependents in their families have higher levels of financial literacy. Probably that happens because more dependents are paying greater attention to the economic situation of the family, and therefore to the level of financial literacy. People with one child have lower levels of financial knowledge than people with two or three children, Servon and Kaestner (2008).

Income levels of the respondents is also an important determining factor for financial literacy. People with a constant income have better conditions to organize and plan their financial life (Calamato, 2010) while unskilled or unemployed workers tends to have lower financial knowledge levels due to less exposure to financial issues, Research (2003). Sometimes, lower financial literacy rates are also related to lower job performance and worker productivity (Kim and Garman, 2004) and shorter spans of employment do not result in gaining knowledge as not much experience in different financial conditions is attained by the people, Volpe (1998).

Educational qualifications of the respondents, especially university education, have an important influence on financial literacy levels too. It is reasonable to estimate that students in economics, administrative management and accounting courses will have a higher level of financial knowledge which was established by Amadeu (2009). It was found that more exposure to finance and economics-related topics in various undergraduate or professional courses has a positive impact on daily financial practice. People with lower education levels are less likely to answer the question correctly and more likely to say that they don't know the answer as compared to people with higher level of education and more access to financial information, Lusardi and Mitchell (2011). Some studies also found that students' knowledge level is not high, especially in investment, irrespective of their qualification course, Chen and Volpe (1998). Similar results were obtained by Mandel (2008) and Lusardi and Mitchell (2007), Lusardi and Tufano (2009) for school students.

Parents' education is also an important demographic variable in the determination of financial education of their children as they play an important role in influencing children's consumption behavior and have a significant influence on their children's knowledge, attitudes and financial management behaviors as found by Jorgensen (2007). Mandell in his study demonstrated that people's financial education and their children's education levels are uniformly linked, Mandell (2008). Research confirms that most people know more about managing funds than their parents, Pinto et al. (2005); Clarke et al. (2005). Research has found that mother's education has a significant positive impact on financial education. The financial status and complexity of the family also have a positive impact on financial education. This conclusion is consistent with the research of Chiteji and Stafford (1999) and Li (2011).

Studies like Johnson and Sherraden (2007) and Atkinson and Messy (2012) study shows that children from high-income families have comparatively better knowledge levels than those from low-income families. Students from low-income families are more likely to drop out of 
school, which in the long run will eventually impact the level of financial literacy negatively, Calamato (2010). People with high levels of financial literacy make better financial decisions and achieve higher income levels while those with low-income levels usually have lower levels of financial knowledge, Montecon (2010) and Hastings and Mitchell (2011) confirmed this with empirical evidence.

\section{Prominent Indian Studies}

Puneet Bhushan et al. (2013), concluded that for salaried persons in Himalayan States, overall literacy rate was very low but the financial literacy rate of men was higher than that of women. Education level, income, nature of employment and workplace affect financial education, while geographical area was not found to be of any significance.

Financial knowledge level of rural women in Tamil Nadu was found to be very low. V Mathavathani et al. (2014) studied the three important factors of knowledge, behavior and attitude.

Financial education level of micro-entrepreneurs in Kangra District, Himachal Pradesh, was evaluated by Kamal Gupta et al. (2014). Based on the knowledge of record keeping, various institutions, savings, investment plans, savings management and various credit products, it was found that most of the respondents knew very little. The research concluded that more awareness and economic options should be created for the financial well-being of these microentrepreneurs.

The Visa Financial Literacy Survey (2012) showed that Indians are the people with very less financial knowledge in the world, and young people and women particularly struggle in this aspect. It concluded that only $25 \%$ of India's population has financial knowledge, ranking it 23 rd out of 28 countries.

In a study of individual investors in Gujarat, India, it was found that financial knowledge has a statistically significant impact on investment decisions. $39.2 \%$ people seemed to have a high level of financial knowledge, Harsha V Jariwala (2014).

It is important to know financial literacy and financial inclusion and their current status, as well as ordinary people's views on financial tools. Lavanya Rekha Bahadur (2015) analyzed the data which came from people in the Mumbai and Tanner regions. Level of financial education was found to be very low. For laying a solid foundation of financial education, it was concluded that these skills must be inculcated from a very young age in schools through local, regional and national-level programs.

Some studies have confirmed that most professional women know the investment avenue and invest their savings in fixed deposits in banks and post offices. Priyanka Agarwal et al. (2015) emphasized the importance of financial education to females working in the education sector in Jhansi (Uttar Pradesh, India).

Indian women's financial attitudes were studied from the point of view of nine variables namely, anxiety, interest in financial issues, intuitive decisions, preventive savings, free spending, materialism and fatalistic attitude, the tendency to plan short-term and long-term financial goals. The study concluded that only one-third of the respondents did not purchase financial products, and most preferred products were fixed and safe deposits, Paluri and Mehra (2016).

\section{OBJECTIVES OF THE STUDY}

- To understand whether the level of financial literacy among youth in India is at par with the level of financial literacy among youth in the world. 
Analysing the Socio Demographic Factors Affecting Financial Literacy of the Indian Youth: A

Special Case of College Students in Himalayan Region

- To identify the prominent demographic variables affecting financial literacy in youth in India.

- To develop a model to identify the determinants of financial literacy among youth in India.

- To suggest strategies to utilize and implement this socio-demographic model.

\section{RESEARCH METHODOLOGY}

\subsection{Study Variables}

This study aimed to identify prominent demographic variables affecting financial literacy in youth studying in Northern Himalayan region of India so the next logical step was to propose a model that demonstrates a relationship between all such important demographic variables. The prime binary variable to be studied in this study is Overall Financial Knowledge which covers all the important dimensions of financial literacy among youth. This variable is further affected by three important dependent variables namely General Financial Knowledge, Personal Financial Planning and Risk Management. Several independent variables describing the demographic profile of the respondents were also identified in order to measure these dependent variables. These independent variables are namely gender, age, native state of residence, education, parents' educational qualification, their professions etc. Another important aspect to be studied here was the influence of parents' personal financial attitude, their nurturing towards financial planning and their behaviour as role models in financial matters. Finally attitude of the young respondents towards financial planning in their life was also studied by covering several aspects of record keeping, financial knowledge, behaviour of the respondents in various financial conditions. This is all explained in Figure 3.

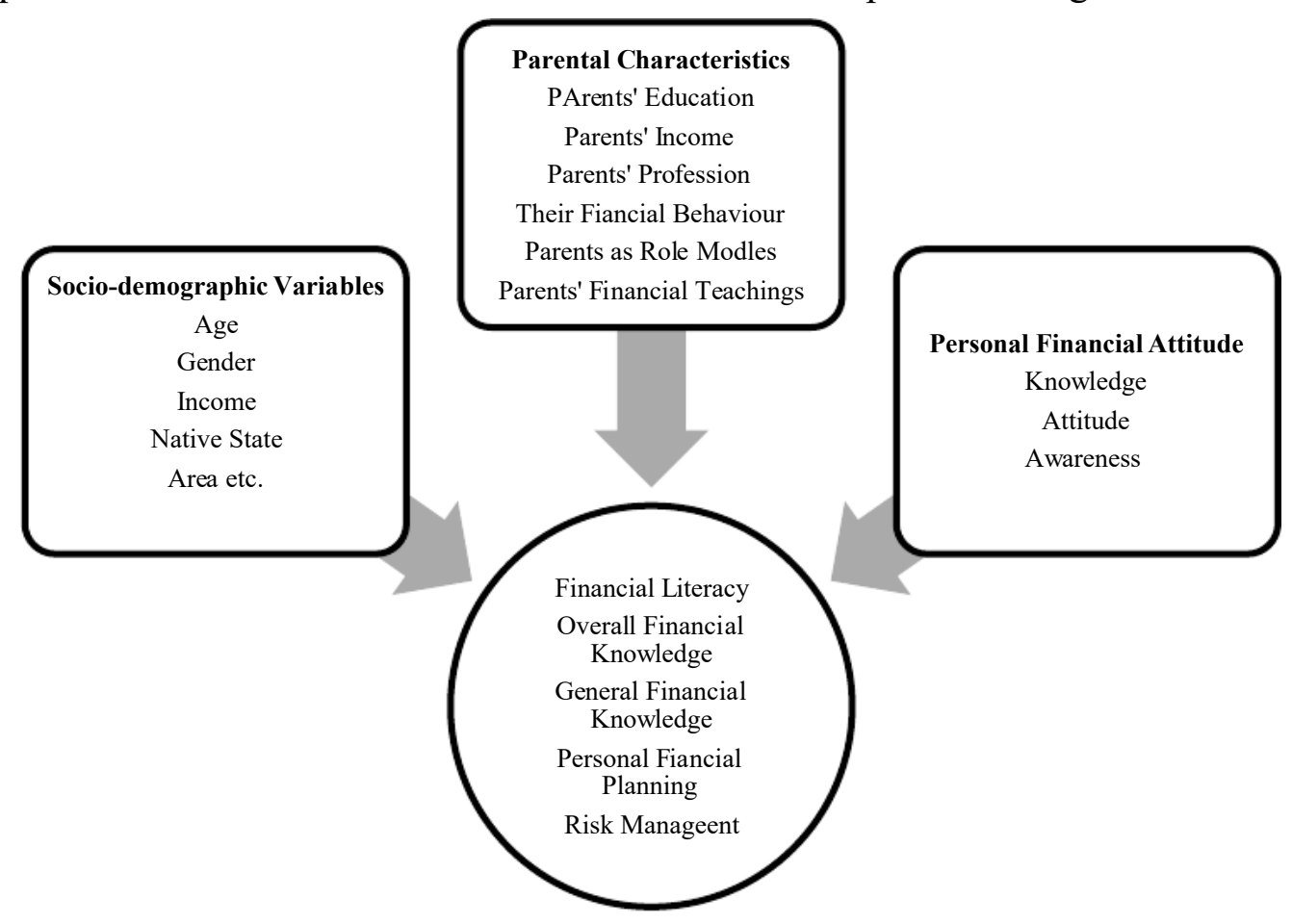

Figure 3 The Conceptual Model

Source: Authors 


\subsection{Research Hypotheses}

The following research hypotheses were formulated for the purpose of studying the important socio-demographic variables:

H1: Level of financial literacy is expected to increase with the age of young individuals.

$\mathrm{H} 2$ : Men are expected to have higher financial literacy levels than women.

H3: The education level of an individual is likely to be directly proportional to their financial literacy level.

H4: Financial literacy of the individual is likely to increase as the number of dependent family members increases.

H5: Parents' education level is likely to have a positive impact on the individual's financial literacy levels.

H6: The family income is more likely to have a positive influence on the individual's financial literacy levels.

H7: Young individuals are more likely to follow the financial attitudes and behaviours of their parents.

H8: Young individuals with exposure to financial concepts since an early age are more likely to have higher financial literacy levels than those with no such exposure.

\subsection{Sample and Research Instrument}

The research was conducted in the northern states of India, namely Uttar Pradesh, Uttarakhand, Punjab, Haryana and Himachal Pradesh. The target population consisted of young individuals in the age group of 18-30 years studying in different colleges in these states.

The population of youth in these states is around 4 crores and considering this, adopting a sampling process with 95\% confidence level and 5\% sampling error, a sample of 385 respondents was required to be obtained. The questionnaire was distributed according to the number of respondents expected from these regions of the north Indian states. A total of 471 respondents submitted the final response.

A well-structured questionnaire was designed in Google form and administered online through social media groups of around 500 students and consent from them was also taken before actually filling the responses and the intent behind this survey was also conveyed to them. Physical distribution of questionnaire was not possible due to lockdown on account of COVID-19 condition. Out of these 443 respondents' responses were found to be complete and fit to use.

The OECD study has advocated study of financial literacy by covering three important dimensions, namely, financial attitude, financial knowledge and financial behaviour. Our questionnaire had 42 questions and was divided into three parts. The first part had 14 questions on demographic factors, namely: age, gender, education, family income, parents' education etc. The second part comprised of 20 questions on the financial behaviour and attitude which covered aspects about the saving habits of the participants, the way their financial behaviour is influenced by the conditioning of their parents and finally the third part of questionnaire covered 8 questions about the financial knowledge of the participants like basic understanding of the financial terms and current financial concepts. Most of the questions were close ended and those measuring financial behaviour and attitude were majorly based on 5-point Likert scale. The correct answer was assigned the value of 1 and every wrong answer was assigned the value of 0 . Finally, the score of every respondent in every section as well as the total score was calculated. 
Analysing the Socio Demographic Factors Affecting Financial Literacy of the Indian Youth: A

Special Case of College Students in Himalayan Region

\subsection{Sample Profile}

Data collection was done from 443 respondents, almost equally represented by men (51\%) and women (49\%). Almost $50 \%$ of the respondents belonged to the age group of 18-20 years and the next largest age group was 20-22 years. Nearly half of the respondents belonged to urban areas $(47.2 \%)$ and majority of them had not yet reached the level of post graduate education (73.6\%). (Table 1)

Table 1 Socio-demographic Profile of the Entire Sample

\begin{tabular}{|c|c|c|c|}
\hline & & $\begin{array}{c}\text { No. of } \\
\text { Participants }\end{array}$ & Percentage \\
\hline 1. & Gender & & \\
\hline a) & Male & 226 & 51 \\
\hline b) & Female & 217 & 49 \\
\hline 2. & Age & & \\
\hline a) & $18-20$ yrs & 235 & 53 \\
\hline b) & $20-22$ yrs & 117 & 26.4 \\
\hline c) & $22-25$ yrs & 70 & 15.8 \\
\hline d) & $25-28$ yrs & 21 & 4.7 \\
\hline 3. & Family Members & & \\
\hline a) & $0-2$ & 3 & 0.7 \\
\hline b) & $3-4$ & 193 & 43.6 \\
\hline c) & $5-6$ & 176 & 39.7 \\
\hline d) & More than 6 & 71 & 16 \\
\hline 4. & Native State & & \\
\hline & Uttarakhand & 219 & 49.4 \\
\hline b) & Uttar Pradesh & 76 & 17.2 \\
\hline & Bihar & 43 & 9.7 \\
\hline & NCR, J\&K, HP & 35 & 7.9 \\
\hline e) & Others & 70 & 15.8 \\
\hline 5. & Area & & \\
\hline & City & 166 & 37.5 \\
\hline & Large City & 43 & 9.7 \\
\hline & Small Town & 38 & 8.6 \\
\hline & Town & 80 & 18.1 \\
\hline & Village & 23 & 5.2 \\
\hline f) & Don't Know & 93 & 21 \\
\hline 6. & Education & & \\
\hline & Intermediate (XI-XII) & 159 & 35.9 \\
\hline & Graduate & 167 & 37.7 \\
\hline
\end{tabular}




\begin{tabular}{|c|c|c|}
\hline Post graduate & 55 & 12.4 \\
\hline d) Professional course & 62 & 14 \\
\hline \multicolumn{3}{|l|}{ 7. $\quad$ Father's Education } \\
\hline a) Graduate & 175 & 39.5 \\
\hline b) Post graduate & 69 & 15.6 \\
\hline c) Professional Degree & 199 & 44.9 \\
\hline \multicolumn{3}{|l|}{ 8. Mother's Education } \\
\hline a) Up to Graduate & 153 & 34.5 \\
\hline b) Post Graduate & 76 & 17.2 \\
\hline c) Professional Degree & 214 & 48.3 \\
\hline \multicolumn{3}{|l|}{ 9. Father's Profession } \\
\hline a) Businessman & 146 & 33 \\
\hline b) $\quad$ Farmer & 63 & 14.2 \\
\hline c) Govt. Employee & 124 & 28 \\
\hline d) Pvt. Employee & 65 & 14.7 \\
\hline e) $\quad$ Professional & 9 & 2 \\
\hline \multirow{2}{*}{$\begin{array}{l}\text { f) } \quad \text { Retired } \\
\text { 10. } \text { Mother's Profession }\end{array}$} & 36 & 8.1 \\
\hline & & \\
\hline a) $\quad$ Business & 11 & 2.5 \\
\hline b) Govt. Employee & 24 & 5.4 \\
\hline c) Housewife & 386 & 87.1 \\
\hline d) Pvt. Employee & 20 & 4.5 \\
\hline \multicolumn{3}{|l|}{ e) $\quad$ Professional } \\
\hline \multicolumn{3}{|l|}{ 11. Primary Earner } \\
\hline a) Both & 44 & 9.9 \\
\hline b) $\quad$ Father & 376 & 84.9 \\
\hline c) Mother & 23 & 5.2 \\
\hline \multicolumn{3}{|c|}{ 12. Family's Monthly Income } \\
\hline a) More than $1,00,000$ & 49 & 11.1 \\
\hline b) Upto Rs.1,00,000 & 59 & 13.3 \\
\hline c) Upto Rs.50,000 & 133 & 30 \\
\hline d) Upto Rs.30,000 & 202 & 45.6 \\
\hline 13. Family Accommoda & & \\
\hline a) Ancestral & 33 & 7.4 \\
\hline b) Official & 14 & 3.2 \\
\hline c) Owned & 357 & 80.6 \\
\hline d) $\quad$ Rented & 39 & 8.8 \\
\hline
\end{tabular}

Source: Authors

\section{ANALYSIS AND FINDINGS}

A binary logistic regression model was developed for the analysis of the socio-demographic variables that affect financial literacy. It is important to check the overall fit of the model developed by the study. The method of adjusted $\mathrm{R}^{2}$ was used to check its ability to correctly classify observations for the entire sample, its different sections and all the individual questions. It was found that 73.1 per cent of the observations are correctly classified, as compared to 72.3 per cent chance classification. 
Analysing the Socio Demographic Factors Affecting Financial Literacy of the Indian Youth: A Special Case of College Students in Himalayan Region

In addition to checking the overall fit of the model, the fit of the three models namely General Financial Knowledge, Personal Financial Planning and Risk Management was also required to be checked individually. The models for Personal Financial Planning and Risk Management were found to be fit but the model for General Financial Knowledge was not found to be fit. Hence it was not considered while analysing the model for Overall Financial Knowledge. The significant results in all the important dimensions covered in separate sections of the questionnaire are as discussed below (Refer Table 2 for details).

Table 2 Mean Percentile of Correct Responses to Each Survey Question, Each Section and the Entire Sample

\begin{tabular}{|l|c|c|c|}
\hline \multirow{2}{*}{\multicolumn{1}{|c|}{ Variables }} & \multicolumn{2}{c|}{ Level of Personal Financial Knowledge } \\
\cline { 2 - 4 } & $\begin{array}{c}\text { Low } \\
\text { (Below 60\%) }\end{array}$ & Medium (60-80\%) & $\begin{array}{c}\text { High } \\
\text { (Over 80\%) }\end{array}$ \\
\hline Overall Financial Knowledge & 48.31 & & \\
\hline Personal Financial Planning & 50.03 & & \\
\hline Personal Financial literacy helps & & 63.2 & \\
\hline Personal Financial Planning Items & & 60 & \\
\hline Retirement Planning & 26.9 & & \\
\hline Risk Management & 40.7 & & \\
\hline $\begin{array}{l}\text { Reasons for purchasing Life } \\
\text { Insurance }\end{array}$ & 47.9 & & \\
\hline $\begin{array}{l}\text { Reasons for purchasing Health } \\
\text { Insurance }\end{array}$ & 33.4 & & \\
\hline General Financial Knowledge & 51.7 & & \\
\hline Overdraft & 53 & & \\
\hline CIBIL Score & 54.2 & & \\
\hline Guarantee on a loan & 47.9 & & \\
\hline
\end{tabular}

Source: Authors

Table 3 Estimated Coefficients and the Level of Significance

\begin{tabular}{|l|c|c|c|c|c|c|}
\hline ITEMS & \multicolumn{2}{|c|}{$\begin{array}{c}\text { Overall Financial } \\
\text { Knowledge }\end{array}$} & \multicolumn{2}{c|}{$\begin{array}{c}\text { Personal Financial } \\
\text { Planning }\end{array}$} & \multicolumn{2}{c|}{ Risk Management } \\
\hline & Beta & $\begin{array}{c}\text { Exp } \\
\text { (B) }\end{array}$ & Beta & Exp (B) & Beta & Exp (B) \\
\hline Gender & -.119 & .888 & -.112 & .894 & -.042 & .959 \\
\hline Age & & & & & & \\
\hline Age (1) & -.857 & .425 & .231 & 1.260 & - & .215 \\
\hline Age (2) & -.537 & .584 & -.074 & .929 & -.538 & .584 \\
\hline No. of Family Members & & & & & & \\
\hline No. of Family Members (1) & -21.654 & .000 & -22.124 & .000 & -22.031 & .000 \\
\hline No. of Family Members (2) & .478 & 1.613 & -.115 & .891 & -.105 & .900 \\
\hline No. of Family Members (3) & .355 & 1.426 & -.112 & .894 & -.295 & .745 \\
\hline
\end{tabular}


Divya Ghai and Praveen Singh

\begin{tabular}{|c|c|c|c|c|c|c|}
\hline \multicolumn{7}{|l|}{ Native State of Residence } \\
\hline Native State of Residence (1) & .370 & 1.447 & -.025 & .975 & -.011 & .989 \\
\hline Native State of Residence (2) & .003 & 1.003 & -.260 & .771 & -.572 & .564 \\
\hline Native State of Residence (3) & $.947 *$ & 2.579 & -.567 & .567 & .407 & 1.502 \\
\hline Native State of Residence (4) & .212 & 1.236 & -.097 & .907 & -.073 & .930 \\
\hline \multicolumn{7}{|l|}{ Area to which you belong } \\
\hline Area to which you belong (1) & .128 & 1.137 & -.395 & .674 & -.302 & .739 \\
\hline Area to which you belong (2) & .339 & 1.404 & .503 & 1.653 & .099 & 1.104 \\
\hline Area to which you belong (3) & $1.358 * *$ & 3.890 & .015 & 1.015 & .592 & 1.808 \\
\hline Area to which you belong (4) & .544 & 1.722 & .222 & 1.248 & .087 & 1.091 \\
\hline Area to which you belong (5) & .003 & 1.003 & .386 & 1.471 & -.496 & .609 \\
\hline \multicolumn{7}{|l|}{ Educational Qualification } \\
\hline Educational Qualification (1) & -.083 & .920 & -.405 & .667 & $.885^{* *}$ & 2.424 \\
\hline Educational Qualification (2) & -.451 & .637 & .130 & 1.139 & .275 & 1.316 \\
\hline Educational Qualification (3) & $-1.207 * *$ & .299 & -.489 & .613 & $-.969 * *$ & .380 \\
\hline \multicolumn{7}{|l|}{ Father's Education } \\
\hline Father's Education (1) & -.039 & .962 & .326 & 1.385 & -.106 & .900 \\
\hline Father's Education (2) & .054 & 1.055 & -.152 & .859 & .212 & 1.236 \\
\hline \multicolumn{7}{|l|}{ Mother's Education } \\
\hline Mother's Education (1) & .432 & 1.540 & -.125 & .883 & .477 & 1.611 \\
\hline Mother's Education (2) & -.036 & .965 & $.492 *$ & 1.636 & -.213 & .809 \\
\hline \multicolumn{7}{|l|}{ Father's Profession } \\
\hline Father's Profession (1) & -.503 & .605 & -.220 & .803 & .041 & 1.041 \\
\hline Father's Profession (2) & -.834 & .434 & -.165 & .848 & .031 & 1.031 \\
\hline Father's Profession (3) & -.445 & .641 & -.544 & .581 & .470 & 1.599 \\
\hline Father's Profession (4) & $-.937 *$ & .392 & -.392 & .676 & .444 & 1.559 \\
\hline Father's Profession (5) & -.488 & .614 & -.080 & .923 & -.246 & .782 \\
\hline \multicolumn{7}{|l|}{ Family's Monthly Income } \\
\hline Family's Monthly Income (1) & $-.900 * *$ & .406 & -.148 & .863 & $\overline{-}-\overline{1}$ & .356 \\
\hline Family's Monthly Income (2) & .511 & 1.667 & -.261 & .770 & $.804 *$ & 2.235 \\
\hline Family's Monthly Income (3) & -.233 & .792 & $-.537 *$ & .585 & -.099 & .906 \\
\hline \multicolumn{7}{|l|}{$\begin{array}{l}\text { Main Financial Decision Maker } \\
\text { in the family }\end{array}$} \\
\hline $\begin{array}{l}\text { Main Financial Decision Maker } \\
\text { in the family (1) }\end{array}$ & -.167 & .846 & -.409 & .664 & .221 & 1.247 \\
\hline
\end{tabular}


Analysing the Socio Demographic Factors Affecting Financial Literacy of the Indian Youth: A Special Case of College Students in Himalayan Region

\begin{tabular}{|c|c|c|c|c|c|c|}
\hline $\begin{array}{l}\text { Main Financial Decision Maker } \\
\text { in the family (2) }\end{array}$ & .209 & 1.233 & .916 & 2.500 & -.454 & .635 \\
\hline $\begin{array}{l}\text { Main Financial Decision Maker } \\
\text { in the family (3) }\end{array}$ & .357 & 1.428 & .350 & 1.419 & .193 & 1.213 \\
\hline \multicolumn{7}{|l|}{ Parents' Financial Attitude } \\
\hline $\begin{array}{l}\text { Parents Manage Family Expenses } \\
\text { Well }\end{array}$ & .028 & 1.028 & $-.211^{* *}$ & .810 & .071 & 1.073 \\
\hline $\begin{array}{l}\text { Parents regularly track their } \\
\text { monthly income }\end{array}$ & .016 & 1.017 & $-.310^{*}$ & .733 & $-.354^{*}$ & .702 \\
\hline $\begin{array}{l}\text { Parents Spend within their } \\
\text { budget }\end{array}$ & $.471 * *$ & 1.601 & .027 & 1.027 & .230 & 1.259 \\
\hline $\begin{array}{l}\text { Parents pay their credit card } \\
\text { dues in full each month }\end{array}$ & .192 & 1.211 & .288 & 1.333 & -.102 & .903 \\
\hline $\begin{array}{l}\text { Parents save money each month } \\
\text { for future }\end{array}$ & .327 & 1.387 & .005 & 1.005 & .224 & 1.251 \\
\hline $\begin{array}{l}\text { Parents invest for long term } \\
\text { financial goals regularly }\end{array}$ & -.126 & .881 & .053 & 1.054 & -.046 & .955 \\
\hline Family's major expenditure & .090 & 1.094 & .096 & 1.101 & .194 & 1.215 \\
\hline \multicolumn{7}{|l|}{$\begin{array}{l}\text { Parents' Nurturing Towards } \\
\text { Financial Planning }\end{array}$} \\
\hline $\begin{array}{l}\text { Discuss family financial matters } \\
\text { with me }\end{array}$ & $.556^{* *}$ & 1.744 & .098 & 1.103 & .428 & 1.533 \\
\hline $\begin{array}{l}\text { Talk to me about the importance } \\
\text { of savings }\end{array}$ & -.424 & .655 & .160 & 1.174 & -.602 & .548 \\
\hline $\begin{array}{l}\text { Teach me how to be a smart } \\
\text { shopper }\end{array}$ & -.192 & .825 & .199 & 1.220 & -.164 & .848 \\
\hline $\begin{array}{l}\text { Advise me how to use my pocket } \\
\text { money appropriately }\end{array}$ & -.426 & .653 & -.102 & .903 & -.116 & .891 \\
\hline $\begin{array}{l}\text { Discuss with me about my college } \\
\text { education expenditure }\end{array}$ & -.087 & .917 & -.423 & .655 & -.153 & .858 \\
\hline $\begin{array}{l}\text { Parents taught you financial } \\
\text { thumb rules }\end{array}$ & -.090 & .914 & $-.199 *$ & .819 & .116 & 1.123 \\
\hline \multicolumn{7}{|l|}{$\begin{array}{l}\text { Parents' as role models in } \\
\text { Financial Matters }\end{array}$} \\
\hline $\begin{array}{l}\text { Do as your parent(s) have done in } \\
\text { similar situations }\end{array}$ & .055 & 1.057 & -.064 & .938 & .067 & 1.069 \\
\hline $\begin{array}{l}\text { Look up to your parent(s) as your } \\
\text { role model(s) }\end{array}$ & -.001 & .999 & .222 & 1.249 & -.058 & .944 \\
\hline $\begin{array}{l}\text { Think of what your parents have } \\
\text { taught you and use your own } \\
\text { knowledge to take a decision }\end{array}$ & -.214 & .807 & .415 & 1.514 & $1.009^{-} * *$ & .365 \\
\hline $\begin{array}{l}\text { Parent(s) has/have positive } \\
\text { influence on you when it comes to } \\
\text { managing money }\end{array}$ & -.203 & .817 & .101 & 1.107 & .228 & 1.256 \\
\hline $\begin{array}{l}\text { Think what your parents did } \\
\text { during difficult financial times }\end{array}$ & .147 & 1.158 & -.111 & .895 & .031 & 1.032 \\
\hline $\begin{array}{l}\text { Feeling about money during } \\
\text { crisis }\end{array}$ & $.366^{* *}$ & 1.443 & .165 & 1.179 & .131 & 1.140 \\
\hline $\begin{array}{l}\text { Attitude Towards Financial } \\
\text { Planning }\end{array}$ & & & & & & \\
\hline
\end{tabular}


Divya Ghai and Praveen Singh

\begin{tabular}{|c|c|c|c|c|c|c|}
\hline Maintain financial records & -.151 & .860 & -.156 & .856 & -.053 & .948 \\
\hline $\begin{array}{l}\text { Maintaining adequate financial } \\
\text { records }\end{array}$ & .063 & 1.065 & .083 & 1.086 & .017 & 1.018 \\
\hline Spend less than income & $.546^{* *}$ & 1.726 & -.054 & .947 & $.445^{* *}$ & 1.561 \\
\hline $\begin{array}{l}\text { Maintain adequate insurance } \\
\text { coverage }\end{array}$ & .188 & 1.207 & .149 & 1.161 & .075 & 1.077 \\
\hline $\begin{array}{l}\text { Plan and implement a regular } \\
\text { investment program }\end{array}$ & -.070 & .932 & -.124 & .884 & -.006 & .994 \\
\hline \multicolumn{7}{|l|}{ Financial Planning } \\
\hline Comparison with parents & $.209 * *$ & 1.233 & -.045 & .956 & .026 & 1.026 \\
\hline $\begin{array}{l}\text { Surety about ability to manage } \\
\text { own finances }\end{array}$ & $.293 * *$ & 1.341 & $.197 *$ & 1.218 & .165 & 1.180 \\
\hline $\begin{array}{l}\text { Interest in increasing financial } \\
\text { knowledge }\end{array}$ & .112 & 1.118 & -.005 & .995 & .043 & 1.044 \\
\hline $\begin{array}{l}\text { Keeping track of expenses on a } \\
\text { regular basis }\end{array}$ & $.362 * *$ & 1.436 & .190 & 1.209 & $.238^{*}$ & 1.269 \\
\hline $\begin{array}{l}\text { Putting money aside for savings, } \\
\text { future purchases, or emergencies }\end{array}$ & $-.225^{*}$ & .799 & .154 & 1.167 & -.038 & .963 \\
\hline $\begin{array}{l}\text { Paying credit card bills on time } \\
\text { each month }\end{array}$ & .117 & 1.124 & $.283 * *$ & 1.327 & .041 & 1.042 \\
\hline Preparing a budget every month & -.084 & .919 & $-.305^{* *}$ & .737 & .000 & 1.000 \\
\hline $\begin{array}{l}\text { Making and discussing goals } \\
\text { about expenses with my family }\end{array}$ & .089 & 1.093 & -.055 & .946 & -.058 & .943 \\
\hline $\begin{array}{l}\text { Comparing-shop or buying } \\
\text { things on sale }\end{array}$ & $.235^{*}$ & 1.265 & $.232 *$ & 1.261 & -.053 & .948 \\
\hline $\begin{array}{l}\text { Feeling secure in my current } \\
\text { financial situation }\end{array}$ & -.085 & .919 & .020 & 1.021 & .007 & 1.007 \\
\hline Overall chi-square & 137.193 & & 103.666 & & 100.039 & \\
\hline Correct Classification & 73.1 & & 71.1 & & 72.2 & \\
\hline Chance & 72.3 & & 80.2 & & 85.1 & \\
\hline Constant & $-6.785 * *$ & & -1.085 & & -.823 & \\
\hline -2 Log likelihood & 476.915 & & 504.106 & & 486.993 & \\
\hline Adjusted $\mathbf{R}^{2}$ & .355 & & .280 & & .275 & \\
\hline
\end{tabular}

Source: Authors

Notes: $*=$ significant at 0.1 level

** = significant at 0.05 level

Gender $=1$ if the participant is female, 0 otherwise (base is male)

Age $(1)=1$ if a participant is aged between 22 and 25 years, 0 otherwise

Age (2) = if a participant is aged between 25 and 28 years, 0 otherwise. (base age 20-22 years)

No. of Family Members $=1$ if the respondent has more than 6 family members, 0 otherwise (base more than 6)

No. of Family Members $(1)=1$ if the respondent has up to 2 family members, 0 otherwise

No. of Family Members (2) = 1 if the respondent has 3-4 family members, 0 otherwise 
Analysing the Socio Demographic Factors Affecting Financial Literacy of the Indian Youth: A Special Case of College Students in Himalayan Region

No. of Family Members (3) $=1$ if the respondent has 5-6 family members, 0 otherwise

Native State of Residence $=1$ if the respondent's native state of residence is Others, 0 otherwise (base Other states)

Native State of Residence (1) $=1$ if its Uttarakhand, 0 otherwise

Native State of Residence (2) $=1$ if its Uttar Pradesh, 0 otherwise

Native State of Residence (3) $=1$ if its Bihar, 0 otherwise

Native State of Residence (4) $=1$ if its New Delhi, Haryana, Himachal Pradesh or J\&K, 0 otherwise

Area to which you belong $=1$, if the respondent lives in a village or rural area, 0 otherwise (base village or rural area)

Area to which you belong $(1)=1$, if the respondent lives in a city (with 100000 to about 1000000 people), 0 otherwise

Area to which you belong (2) $=1$, if the respondent lives in a large city (with over 1000 000 people), 0 otherwise

Area to which you belong $(3)=1$, if the respondent lives in a small town ( 3000 to about 15 000 people), 0 otherwise

Area to which you belong $(4)=1$, if the respondent lives in a town (15 000 to about 100 000 people), 0 otherwise

Area to which you belong $(5)=1$, if the respondent doesn't know the size of area, 0 otherwise

Educational Qualification $=1$ if a participant is pursuing a professional degree like B.Tech., MBBS etc. or any other, 0 otherwise (base professional degree)

Educational Qualification (1) $=1$ if a participant has done schooling, 0 otherwise

Educational Qualification (2) $=1$ if a participant is graduate, 0 otherwise

Educational Qualification (3) = 1 if a participant is post-graduate, 0 otherwise

Father's Education $=1$ if father of the respondent is graduate, 0 otherwise (base is graduate)

Father's Education (1) $=1$ if father is post graduate, 0 otherwise

Father's Education (2) $=1$ if father has professional qualification like Law, Medical, Engineering etc. or any other, 0 otherwise

Mother's Education $=1$ if mother of the respondent has done Class XII, 0 otherwise (base Class XII)

Mother's Education (1) $=1$ if mother is graduate, 0 otherwise

Mother's Education (2) $=1$ if mother is post graduate, 0 otherwise

Father's Profession $=1$ if the respondent's father is retired, 0 otherwise (base retired)

Father's Profession (1) $=1$ if father is a businessman, 0 otherwise

Father's Profession (2) $=1$ if father is a farmer, 0 otherwise

Father's Profession (3) $=1$ if father is a government employee, 0 otherwise

Father's Profession (4) $=1$ if father is a private employee, 0 otherwise

Father's Profession (5) = 1 if father is professional like Doctor, Lawyer etc., 0 otherwise

Family's Monthly Income $=1$ if the income is up to Rs.50,000, 0 otherwise (base 50,000)

Family's Monthly Income (1) $=1$ if the income is more than Rs. 1,00,000, 0 otherwise

Family's Monthly Income (2) $=1$ if the income is up to Rs. 1,00,000, 0 otherwise

Family's Monthly Income (3) $=1$ if the income is up to Rs.30,000, 0 otherwise 
Main Financial Decision Maker in the family=1, if both the parents of the respondent make financial decisions, 0 otherwise

Main Financial Decision Maker in the family (1) =1, if Father makes financial decisions, 0 otherwise

Main Financial Decision Maker in the family (2) $=1$, if Grandparents make financial decisions, 0 otherwise

Main Financial Decision Maker in the family (3) = 1, if Mother makes financial decisions, 0 otherwise

The proposed logistic regression model is as follows: (Refer Table 3 for details)

$\log [p /(1-p)]=B 0+B 1($ Age1) + B2 (Native State of Residence3) + B3 (Area to which you Belong3) + B4 (Educational Qualification1) + B5 (Educational Qualification3) + B6 (Mother's Education2) + B7 (Father's Profession4) + B8 (Family's Monthly Income1) + B9 (Family's Monthly Income2) + B10 (Family's Monthly Income3) + B11 (Parents' Financial Attitude) + B12 (Parents' Nurturing Towards Financial Planning) + B12 (Parents as Role Models in Financial Matters) + B13 (Attitude Towards Financial Planning) + B14 (Good Financial Planning)

Where $p=$ the probability of a youth having better financial knowledge

\subsection{Overall Financial Knowledge}

Among the independent demographic variables gender of the respondents does not seem to have a significant impact on the overall financial knowledge which is very surprising but indicates towards a very positive aspect of young males and females being exposed to the financial literacy concepts to a similar extent. Age and number of family members also did not show any significant impact on the financial knowledge overall.

A significant observation about the native place of residence is that the respondents residing in Bihar are 2.579 times more likely to possess better overall financial knowledge as compared to the respondents residing in other states. This must be due to general curious nature of the young people from this state.

Another interesting observation is that the respondents residing in small towns with an approx. population of 3000-15000 are 3.89 times more likely to be better in overall financial knowledge in comparison to a respondent living in a village or rural area which confirms the general belief that the respondents living in urban areas have more exposure of financial literacy as compared to those in rural areas.

Educational qualification seems to be an important variable impacting financial literacy as the respondents with post graduate qualifications are 0.299 times more likely to have better levels of overall financial knowledge as compared to those pursuing professional degrees. (H3 accepted)

Education of both the parents does not demonstrate any noticeable difference for the overall financial knowledge of the young respondent. But if a respondent's father is working as a private employee, the respondent is 0.392 times more likely to possess better financial knowledge vis a vis those whose father is a retired individual which shows the active involvement by a father who must be updated about financial aspects.

When the respondent belongs to a family with monthly income of more than Rs.1,00,000, the overall financial knowledge of the respondent is likely to be 0.406 times high compared to a respondent from a family with Rs.50,000 as the monthly income which seems a logical conclusion as a family with higher income has more avenues to talk about finances openly. (H6 accepted) 
Analysing the Socio Demographic Factors Affecting Financial Literacy of the Indian Youth: A

Special Case of College Students in Himalayan Region

Parents' financial attitude seems to have a positive impact on the respondent's nurturing towards financial planning and overall financial knowledge as it turns out to be higher for those respondents who have been brought up by parents with good financial habits like spending within their budget (by 1.601 times); discussing family financial matters with the young members of the family (by 1.744 times); and spending less than their income (by 0.546 times). (H7 accepted)

If the respondent feels comfortable about money during crisis, then they are 1.443 times more likely to possess better overall financial knowledge which shows their inherent confidence in matters relating to finance is majorly due to their parents having acted as the role models.

The respondents seem to be good at overall financial knowledge and eventually at financial planning due to a positive mental perception of comparing themselves with their parents $(B=1.233, p=0.05)$; the characteristic of being sure about their ability to manage their own finances $(B=1.341, p=0.05)$; keeping track of one's own expenses on a regular basis $(B=1.436$, $\mathrm{p}=0.05$ ); putting aside money for savings, future purchases, or emergencies and compare shop or buy things on sale $(B=0.799 p=0.1$ and $B=1.265 p=0.1$ respectively). (H8 accepted)

\subsection{Personal Financial Planning}

The demographic variables of gender, age, number of family members, native state of residence, area to which they belong, educational qualification of the respondents, and father's education did not show any relevance for analyzing the Personal Financial Planning parameter of the financial literacy among the youth.

Personal Financial Planning is an important parameter of the respondent's level of financial literacy and the mother's education seems to be an important factor impacting it as when the mother is a post graduate the respondent is 1.636 times more likely to have better understanding of the personal financial planning $(\mathrm{B}=1.636 \mathrm{p}=0.1)$ ( $\mathrm{H} 5$ accepted $)$

When the respondent's family income is only upto Rs.30,000, he seems to be better at the personal financial planning which must be the case as he has seen his parents planning the expenses meticulously and managing well within the limited resources $(B=0.585 \mathrm{p}=0.1 \mathrm{PFP})$ (H6 accepted)

Personal financial planning skills of any respondent seem to be positively affected by the characteristic features of their families as they seem to be inculcating all the important good habits since early age like managing their expenses well $(B=0.810 \mathrm{p}=0.05)$, regularly tracking their monthly expenses $(B=0.733 p=0.1)$, teaching them financial thumb rules $(B=0.819$ $\mathrm{p}=0.1)$, paying their credit card bills on time each month $(\mathrm{B}=1.327 \mathrm{p}=0.05)$, preparing a budget every month $(\mathrm{B}=0.737 \mathrm{p}=0.05)$ and as simple and regular as comparing-shop or buying things on sale $(B=1.261 \mathrm{p}=0.1)$. Better personal financial planning knowledge also creates surety about the respondent's ability to manage own expenses by 1.218 times. (H8 accepted)

\subsection{Risk Management}

Key demographic variables like gender, number of family members, native state of residence, area to which the respondents belong did not create any significant difference to the knowledge of risk management among the young respondents.

Respondents of the age group 22-25 yrs. seem to be 0.215 times more likely to have better risk management knowledge as compared to the respondents of the age group 20-22 yrs. which is quite understandable as the respondents of 22-25 yrs. are more mature and have started taking life and its risks seriously. (H1 accepted)

Respondents who are about to join college after completing schooling and those who are post graduates are more likely (2.424 and 0.380 times respectively) to possess better risk 
management knowledge as compared to professionals who may not be exposed to such knowledge commonly. (H3 accepted)

When the family income is more than Rs. $1,00,000(\mathrm{~B}=0.356 \mathrm{p}=0.05)$ or is up to Rs. $1,00,000(\mathrm{~B}=2.235 \mathrm{p}=0.1)$ then the respondents are more likely to know more about risk management as compared to a respondent from a family with income of only Rs.50,000 which may be because a family with higher disposable income has more opportunities to invest in risk management avenues and hence this discussion in such families is quite common. (H6 accepted)

Those respondents are more likely to be better at-risk management knowledge who keep track of their expenses on a regular basis $(B=1.269 \mathrm{p}=0.1)$ and their parents track their monthly expenses too $(B=0.702 p=0.1)$. $(\mathrm{H} 7$ accepted $)$

Better risk management knowledge and understanding is quite evident in those respondents who think of what their parents have taught them and use their own knowledge to take a decision on the financial matters $(\mathrm{B}=0.365 \mathrm{p}=0.05)$ and as a result probably spend less than their income $(\mathrm{B}=1.561 \mathrm{p}=0.05)$. $(\mathrm{H} 8$ accepted $)$

\subsection{Absolutely Irrelevant Variables}

Gender (H2 rejected), number of family members (H4 rejected), father's education and the main financial decision maker in the family have come out to be totally irrelevant variables for the entire model as they don't seem to create any significant impact on the financial literacy of the young respondents.

\section{DISCUSSION AND CONCLUSION}

The most recent economic crisis that happened due to the onset of COVID-19 demonstrated the importance of financial literacy and planning yet again. Lakhs of people lost their jobs all over the world and suddenly were faced with grave financial crisis which shows the glaring lack of financial planning and absence of following any financial thumb rules. If they would have been aware about financial planning and had followed the general financial thumb rules, they would have been prepared to face a crisis for a few months at the least. This reiterates the importance of high levels of financial literacy among our youth so that they are always prepared for such an impending financial crisis. This has become all the more important due to the increasingly complex financial products and services available. A young individual might get confused and discouraged to understand and explore the intricacies of the financial world and this will further have a negative impact on our objective of having financially aware youth. Therefore, the study offers important insights for parents, academicians as well as the policymakers who need to understand the importance of financial literacy being made an essential part of curriculum for everyone.

\section{Key Insights:}

- This study finds that the various socio-demographic variables like age, education, family income, parents' education, their professions, parents' financial behaviour, their financial teachings have significant impact on financial literacy.

- The youth of age 22-25 years scored more on financial literacy than the students in the age group of 20-22 years which proved exposure to financial concepts increased with age.

- The post-graduates scored better than the professionals as these professionals do not get an opportunity to study about financial concepts. Family income also came out as an important influence. This study did not find any significant influence of gender on the levels of financial literacy which is a positive finding. 
Analysing the Socio Demographic Factors Affecting Financial Literacy of the Indian Youth: A

Special Case of College Students in Himalayan Region

- The results confirmed the belief that education of parents has a defining influence on the financial literacy of their children but what was startling was that father's education did not seem to have any major influence but mother's better education had a positive impact on the financial literacy of the children.

- One very important finding here was that the financial behaviour inculcated by parents plays a massive role in defining the financial behaviour of the young adults. This indicates at the important role parents can play in improving the financial knowledge levels of these young individuals.

- Gender, number of family members, father's education and who is the main financial decision maker in the family have come out to be totally irrelevant variables for the study.

\section{IMPLICATIONS OF THE STUDY}

This detailed study points out the important personal, demographic and social variables which create a significant impact on the levels of financial literacy among youth in North India. All the findings clearly show that a lot of focus needs to be brought towards educating and training our youth since early years for improving their knowledge about personal finance. This is the only way to ensure that they are prepared to manage their finances well and make right financial decisions in adult life and do not get trapped in the credit card debt or fraudulent schemes. This will have a very important impact on the financial environment of the country also in the long run as financially aware citizens will participate actively in the financial markets and boost the economy in the process. Investing time, energy and resources on improving the overall financial knowledge of the youth will have long term positive impact for the next generations too.

\section{LIMITATIONS AND FUTURE RELEVANCE}

This study covered respondents from North Indian states only. Geographically segregated studies can provide detailed study of the factors that specifically affect the financial literacy of youth in that area considering the socio-demographic variation in India. Long range panel studies can also be conducted to check the impact of dedicated efforts made towards increasing financial literacy in certain communities or areas across the country or in other countries.

\section{REFERENCES}

[1] Agarwal, Sumit, John C. Driscoll, Xavier Gabaix, and David Laibson. 2009, The Age of Reason: Financial Decisions Over the Life-Cycle with Implications for Regulation, Brookings Papers on Economic Activity 2:51-117.

[2] Agarwalla, S. K., Barua, S. K., Jacob, J., \& Varma, J. R. (2013), Financial Literacy among Working Young in Urban India, Working Paper 2013-10-02, October 2013, Indian Institute of Management, Ahmedabad, India.

[3] Agnew, J. R. and Szykman, L. R. (2005). Asset Allocation and Information Overload: The Influence of Information Display, Asset Choice, and Investor Experience, The Journal of Behavioral Finance, 6(2):57-70. ASIC (2011). National financial literacy strategy. Australian Securities \& Investment Commission Report No. 229. Downloaded from http://www.financialliteracy.gov.au/media/218312/national-financial-literacy-strategy.pdf on 25 August, 2013.

[4] Ajzen, I. (1991). The Theory of Planned Behavior. Organizational Behavior and Human Decision Processes, 50(2), 179-211. https://doi.org/10.1016/0749-5978(91)90020-T 
[5] Amadeu, J. R. (2009). A educação financeira e sua influência nas decisões de consumo e investimento: proposta de inserção da disciplina na matriz curricular. Dissertação de mestrado, Universidade do Oeste Paulista, São Paulo, SP, Brasil.

[6] Atkinson, A. and Messy, F.-A. (2012), Measuring Financial Literacy: Results of the OECD / International Network on Financial Education (INFE) Pilot Study, OECD Working Papers on Finance, Insurance and Private Pensions No. 15, OECD Publishing. Available at http://dx.doi.org/10.1787/5k9csfs90fr4-en.

[7] Brown, M., \& Graf, R. (2013), Financial Literacy and Retirement Planning in Switzerland, Numeracy, 6(2), art. 6. Retrieved on April 10, 2013, from http://scholarcommons.usf.edu/numeracy/vol6/iss2/art6

[8] Calamato, M. P. (2010). Learning Financial Literacy in the Family, Unpublished Master's Thesis, The Faculty of the Department of Sociology, San José State University

[9] Chen, H. \& Volpe, R.P. (1998), An Analysis of Personal Financial Literacy Among College Students. Financial Services Review, 7(2), 107-128.

[10] Chiteji, N. S., \& Stafford, F. P. (1999), Portfolio Choices of Parents and Their Children as Young Adults: Asset Accumulation by African-American families, The American Economic Review, 89(2), 377-380.

[11] Clarke, M. C., Heaton, M. B., Israelsen, C. L., \& Eggett, D. L. (2005), The Acquisition of Family Financial Roles and Responsibilities, Family and Consumer Sciences Research Journal, 33(4), $321-340$

[12] Delavande, A., Rohwedder, S., \& Willis, R. J. (2008). Preparation for Retirement, Financial Literacy and Cognitive Resources. [Working Paper n. 2008-190], Michigan Retirement Research Center, Retrieved on April 25, 2013, from http://www.mrrc.isr.umich.edu/publications/papers/pdf/wp190.pdf.

[13] Edwards, R., Allen, M. W., \& Hayhoe, C. R. (2007), Financial Attitudes and Family Communication about Students' Finances: The role of sex differences, Communication Reports, 20(2), 90-100

[14] Fernandes, D., Lynch, J. G., \& Netemeyer, R. G. (2014), Financial Literacy, Financial Education, and Downstream Financial Behaviors, Management Science, 60(8), 1861-1883.

[15] Harsha V Jariwala, Analysis of Financial Literacy Level of Retail Individual Investors of Gujarat State and Its Effect on Investment Decision, Journal of Business \& Finance Librarianship, November 2014, PP. 133-158.

[16] Hastings, J., \& Mitchell, O. S. (2011), Financial Literacy: Implications for Retirement Security and the Financial Marketplace, Oxford, UK: Oxford University Press.

[17] Huston, S. J. (2010), Measuring Financial Literacy, Journal of Consumer Affairs, 44(2):296316.

[18] Johnson, E., \& Sherraden, M.S. (2007), From Financial Literacy to Financial Capability among Youth, Journal of Sociology and Social Welfare, 34(3), 119-146.

[19] Jorgensen, B. L. (2007), Financial Literacy of College Students: Parental and Peer Influences, Unpublished Master's Thesis, Virginia Polytechnic Institute and State University, Blacksburg, Virginia. 
Analysing the Socio Demographic Factors Affecting Financial Literacy of the Indian Youth: A

Special Case of College Students in Himalayan Region

[20] Kamal Gupta and Jatinder Kaur, A study of Financial Literacy among Micro Entrepreneurs in District Kangra, IJRBM, Vol-2, Issue-2, February 2014, PP. 63-70.

[21] Kim, J., \& Garman, E. T. (2004). Financial Stress, Pay Satisfaction and Workplace Performance, Compensation Benefits Review, 36(1), 69-76

[22] Lavanya Rekha Bahadur, Financial Literacy: The Indian Story, World Journal of Social Sciences, Vol - 5, Issue-3, September 2015, PP. 45-57.

[23] Li, G. (2011), Information Sharing and Stock Market Participation: Evidence from Extended Families, Federal Reserve Board, Downloaded from $\mathrm{http}: / /$ works.bepress.com/cgi/viewcontent.cgi?article=1041\&context=geng_li on 25 August, 2013.

[24] Lusardi, A., \& Wallace, D. (2013). Financial Literacy and Quantitative Reasoning in the High School and College Classroom. Numeracy, 6(2).

[25] Lusardi, A., \& Mitchell, O. S. (2011). Financial Literacy and Retirement Planning in the United States, Journal of Pension Economics and Finance, 10(4), 509-525.

[26] Lusardi, A. and Tufano, P. (2009). Debt Literacy, Financial Experiences, and Overindebtedness, CFS Working Paper No. 2009/08.

[27] Mahapatra, M.S., Alok S. and Raveendran J. (2016), IIM Kozhikode Society and Management Review, 6(2), p.132-147

[28] Mandell, L. (2008), The Financial Literacy of Young American Adults, Retrieved January 13, 2013, from http://www.jumpstart.org/assets/files/2008SurveyBook.pdf

[29] Mccormeck, M. H. (2009), The Effectiveness of Youth Financial Education: A Review of the Literature, Journal of Financial Counseling and Planning, 20(1), 70-83.

[30] Monticone, C. (2010), How Much Does Wealth Matter in the Acquisition of Financial Literacy? The Journal of Consumer Affairs, 44(2), 403-422

[31] Organisation for Economic Co-Operation and Development. OECD. (2013), Financial Literacy and Inclusion: Results of OECD/INFE survey across countries and by gender. OECD Centre, Paris, France.

[32] Pinto, M. B., Parente, D. H., \& Mansfield, P. M. (2005), Information Learned from Socialization Agents: Its Relationship to Credit Card Use, Family and Consumer Sciences Research Journal, 33(4), 357-367.

[33] Priyanka Agarwal, Dr. Suman Yadav, Radhika Kureel, International Journal of Advance Research in Science and Engineering, Vol-1, Issue-1, 2015, PP. 54-61.

[34] Puneet Bhushan, Yajulu Medury, Financial Literacy and its Determinants, International Journal of Engineering, Business and Enterprise Applications (IJEBEA), Vol. 4, Issue -2, May- 2013, PP. 155-160.

[35] Paluri R.A. and Mehra S. (2016), Financial Attitude-based Segmentation of Women in India: An Exploratory Study, Vol. 34 Issue 5, January 2016, PP. 670 - 689.

[36] Research, R. M. (2003). Survey of Adult Financial Literacy in Australia. ANZ Banking Group. Retrieved on April 16, 2013, from http://www.anz.com/Documents/AU/Aboutanz/AN_5654. 
[37] Robb, C. A., Babiarz, P., \& Woodyard, A. (2012). The Demand for Financial Professionals' Advice: The Role of Financial Knowledge, Satisfaction, and Confidence, Financial Services Review, 21(4), 291-305

[38] Scheresberg, C. B. (2013), Financial Literacy and Financial Behaviour Among Young Adults: Evidence and Implications, Numeracy, 6(2)

[39] Servon, L. J., \& Kaestner, R. (2008), Consumer Financial Literacy and the Impact of Online Banking on the Financial Behavior of Lower-income Bank Customers, Journal of Consumer Affairs, 42(2), 271-305.

[40] Shim, S., Barber, B. L., Card, N. A., Xiao, J. J., \& Serido, J. (2010), Financial Socialization of First-Year College Students: The Roles Of Parents, Work, And Education, Journal of Youth and Adolescence, 39(12), 1457-1470.

[41] Thaler, R. H. (2013 October 5), Financial Literacy, Beyond the Classroom, The New York Times. Retrieved on April 3, 2015, from http://www.nytimes.com/2013/10/06/business/financial-literacybeyondtheclassroom.html?r=3\&.

[42] V Mathavathani, Dr. M Velumani, A Study on Financial Literacy Among Rural Women in Tamil Nadu, Indian Journal of Applied Research, Volme-4, Issue-12, December 2014, PP. 556557.

[43] Van Rooij, M. C. J., Lusardi, A., \& Alessie, R. J. M. (2011), Financial Literacy And Retirement Planning in the Netherlands, Journal of Economic Psychology, 32(4), 593-608.

[44] Visa (2012), India Lags in Financial Literacy with Women and Young People Most at Risk. Retrieved October 25, 2016, from http://www.visa.co.in/aboutvisa/mediacenter/NR_INDIA_120612.html

[45] Volpe, R. P., Chen, H., \& Pavlicko, J. J. (1996), Personal Investment Literacy Among College Students: A Survey, Financial Practice and Education, 6(2), 86-94.

[46] Xu, L. and Zia, B. (2012), Financial Literacy Around the World: An Overview of The Evidence With Practical Suggestions For The Way Forward. World Bank Policy Research Working Paper, (6107). 